Article

\title{
Single crystal metal-organic framework constructed by vertically self-pillared nanosheets and its derivative for oriented lithium plating
}

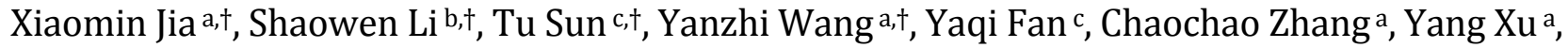 \\ Zuozhong Lianga, Haitao Lei a , Wei Zhang a, Yuye Zhou d, Yanhang Mac, Haoquan Zheng a,*, \\ Yue Ma b,\#, Rui Cao a,\$ \\ ${ }^{a}$ Key Laboratory of Applied Surface and Colloid Chemistry, Ministry of Education, School of Chemistry and Chemical Engineering, Shaanxi Normal \\ University, Xi'an 710119, Shaanxi, China \\ b Center for Nano Energy Materials, State Key Laboratory of Solidification Processing, School of Materials Science and Engineering, Northwestern \\ Polytechnical University, Xi'an 710072, Shaanxi, China \\ ' School of Physical Science and Technology, ShanghaiTech University, Shanghai 201210, China \\ dSchool of Engineering Sciences in Chemistry, Biotechnology and Health, Department of Chemistry, Division of Applied Physical Chemistry, Analytical \\ Chemistry, KTH Royal Institute of Technology, SE-106 91, Stockholm, Sweden
}

\section{A R T I C L E I N F O}

\section{Article history:}

Received 11 December 2020

Accepted 4 January 2021

Available online 5 May 2021

\section{Keywords:}

Vertically self-pillared structure

Metal organic framework

Pre-catalyst preparation

Lithium plating orientation

Metallic battery

\begin{abstract}
A B S T R A C T
This vertically self-pillared (VSP) structure extends the application range of traditional porous materials with facile mass/ion transport and enhanced reaction kinetics. Here, we prepare a single crystal metal-organic framework (MOF), employing the ZIF-67 structure as a proof of concept, which is constructed by vertically self-pillared nanosheets (VSP-MOF). We further converted VSP-MOF into VSP-cobalt sulfide (VSP-CoS 2 ) through a sulfidation process. Catalysis plays an important role in almost all battery technologies; for metallic batteries, lithium anodes exhibit a high theoretical specific capacity, low density, and low redox potential. However, during the half-cell reaction $\left(\mathrm{Li}^{+}+\mathrm{e}=\mathrm{Li}\right)$, uncontrolled dendritic Li penetrates the separator and solid electrolyte interphase layer. When employed as a composite scaffold for lithium metal deposition, there are many advantage to using this framework: 1) the VSP-CoS substrate provides a high specific surface area to dissipate the ion flux and mass transfer and acts as a pre-catalyst, 2) the catalytic Co center favors the charge transfer process and preferentially binds the $\mathrm{Li}^{+}$with the enhanced electrical fields, and 3) the VSP structure guides the metallic propagation along the nanosheet 2D orientation without the protrusive dendrites. All these features enable the VSP structure in metallic batteries with encouraging performances.
\end{abstract}

(C) 2021, Dalian Institute of Chemical Physics, Chinese Academy of Sciences. Published by Elsevier B.V. All rights reserved.

\section{Introduction}

Porous crystalline materials have attracted considerable scientific attention for applications such as catalysis, drug de-

\footnotetext{
*Corresponding author. E-mail: zhenghaoquan@snnu.edu.cn

\# Corresponding author. E-mail: mayue04@nwpu.edu.cn

\$Corresponding author. E-mail: ruicao@snnu.edu.cn

† These authors contributed equally to this work.

This work was supported by the National Natural Science Foundation of China (21975148, 51602261, 51711530037, 21773146, 21835002, 21875140, 21601118), Fok Ying-Tong Education Foundation for Outstanding Young Teachers in University, the Fundamental Research Funds for the Central Universities (GK201903033, 3102019JC005), Shanghai Natural Science Fund (17ZR1418600).

DOI: 10.1016/S1872-2067(20)63755-X | http:/ www.sciencedirect.com/journal/chinese-journal-of-catalysis | Chin. J. Catal., Vol. 42, No. 9, September 2021
} 
livery, separation, and sensors [1-4]. Typical porous crystalline materials, metal-organic framework (MOF) nanosheets, composed of metal ions or clusters and organic ligands, have more open metal sites/certain defects, improved mass transfer, and enhanced performance in catalysis [5-10]. However, uncontrollable aggregation often occurs during synthesis and catalysis, which causes loss of a large number of active sites. Therefore, the design and construction of hierarchical structures using MOF nanosheets is one of the most efficient solutions to this problem [11-18]. Stacked-nanosheet porous zeolites with vertically self-pillared (VSP) structures have been prepared in one pot using two different symmetry structures, and they show enhanced activity in catalysis $[19,20]$. Branches with one lower-symmetry structure are connected by a connector with another higher-symmetry structure. More recently, stacked-nanosheet MOFs have been prepared by selectively etching HKUST-1 along the (111) facets. The angles between the nanosheets are $60^{\circ}$ and $120^{\circ}$, which prevent the material from collapsing [21]. Thus far, it is still difficult to obtain VSP-structured MOFs constructed by nanosheets using a simple synthetic strategy due to its rapid growth rate and uncontrollable nucleation process.

Recently, the transformation of an MOF into its derivatives has been used in energy-dense rechargeable batteries [22-34]. Catalysis plays an important role in almost all battery technologies. Among contemporary metallic batteries, metallic lithium anodes show a theoretical specific capacity (3860 mAh g-1), low density, and low redox potential $(-3.04 \mathrm{~V} v s$ the standard hydrogen electrode, SHE), making it one of the best reported anodes [35]. Uncontrolled dendritic Li forms and breaks the separator and solid electrolyte interphase (SEI) layer. This shortens the lifetime of batteries and causes their failure [36-41]. Since the electrical-field-enhanced tips can induce the preferential deposition of the $\mathrm{Li}^{+}$flux, strategies such as (1) incorporating lithophilic seeds [42-44], (2) geometry control with the homogenized electric fields [45], and (3) 3D design of the deposition substrates [46-48], have been extensively explored. Theoretically, VSP structures are effective for dissipating the ion/mass flux, and thus, mediate the metallic plating process as an ideal plating substrate. However, the simultaneous manipulation of the ion/electron pathway, including the appropriate spatial sites of the metallic embryos for the regulated nucleation, as well as the growth orientation in the VSP hierarchical arrangement, remains a great challenge.

Here, we prepared a single crystal hierarchical MOF composed of VSP nanosheets of the ZIF-67 structure as a proof of concept. These VSP-MOFs are synthesized using Co ions through 2-methylimidazole (Hmim) linkers in a mixed solvent of deionized water and methanol in one pot. An individual VSP-MOF hierarchical particle is a single crystal ZIF-67. Upon sulfidation, this hierarchical VSP-cobalt sulfide structure was well maintained (denoted as VSP-CoS 2 ). This 3D VSP-CoS composite anode was directly evaluated to load the deposited lithium in the metallic batteries. The metallic batteries assembled with the VSP-CoS 2 composite anode exhibited impressive performance, which was attributed to the inhibition of the $\mathrm{Li}$ dendrite through the VSP deposition framework. The structural evolution of VSP-CoS 2 upon cycling and the role of VSP-CoS 2 as pre-catalysts have also been investigated.

\section{Experimental}

\subsection{Preparation of VSP-MOF}

$\mathrm{Co}\left(\mathrm{NO}_{3}\right)_{2} \cdot 6 \mathrm{H}_{2} \mathrm{O}(1 \mathrm{mmol}, 0.291 \mathrm{~g}$ ) and Hmim (6 mmol, 0.492 g) were first dissolved in $15 \mathrm{~mL}$ of mixed solvent (volume ratios, $V_{\text {methanol }} V_{\text {water }}=1: 3.5$ ). Then, the mixture was mixed under stirring for $2.5 \mathrm{~h}$ at room temperature and were kept to age for another $12 \mathrm{~h}$. Finally, purple solid powders were collected by centrifugation (10000 rpm, $5 \mathrm{~min}$ ), washed three times, and then dried overnight in a vacuum freeze dryer. For the synthesis of the $\mathrm{Zn} / \mathrm{Co}$-mixed MOF, $1 \mathrm{mmol}$ of $\mathrm{Co}\left(\mathrm{NO}_{3}\right)_{2}$ was replaced by a mixture of $\mathrm{Co}\left(\mathrm{NO}_{3}\right)_{2}$ and $\mathrm{Zn}\left(\mathrm{NO}_{3}\right)_{2}$. The total amount of $\mathrm{Co}\left(\mathrm{NO}_{3}\right)_{2}$ and $\mathrm{Zn}\left(\mathrm{NO}_{3}\right)_{2}$ was $1 \mathrm{mmol}$.

\subsection{Preparation of VSP-CoS}

VSP-MOF (80 mg) was redispersed in $40 \mathrm{~mL}$ of methanol. TAA $(0.12 \mathrm{~g})$ was added to the above solution. Then, the mixture was sonicated for $1 \mathrm{~min}$. Thereafter, the suspension was transferred to an autoclave and kept at $120^{\circ} \mathrm{C}$ for $4 \mathrm{~h}$. The obtained black powders were centrifuged and washed with methanol. Finally, they were thermally annealed under an $\mathrm{N}_{2}$ atmosphere at $350^{\circ} \mathrm{C}$ for $2 \mathrm{~h}$.

\subsection{Electrochemical measurement}

VSP-CoS 2 composite, Super P carbon black (TIMICAL SUPER C45, Sinopharm Co., Ltd), and polyvinyldifluoride (PVDF, Aldrich) in a weight ratio of 8:1:1 were used as the working electrode and coated on a copper foil to form a VSP-CoS 2 anode. The anode was then dried in a vacuum oven. All cells were assembled in a glove box filled with $\mathrm{Ar}\left(\mathrm{O}_{2}\right.$ and $\mathrm{H}_{2} \mathrm{O}$ contents less than $\left.1 \times 10^{-6}\right)$. The electrochemical properties of various VSP-CoS 2 anodes were evaluated with CR2016 coin cells using Celgard 2400 as a microporous polypropylene film and Li foil as the counter electrode. A mixture of ethylene carbonate, dimethyl carbonate, and ethyl methyl carbonate with a volume ratio of 1:1:1, containing $1 \mathrm{M} \mathrm{LiPF}_{6}$, was prepared. The duration of lithium plating was fixed at $0.2 \mathrm{~h}$, and the current density was fixed at $5 \mathrm{~mA} \mathrm{~cm}^{-2}$, and the cutoff potential of the stripping process was controlled at $1.0 \mathrm{~V}$ on a Neware CT-4008 battery tester. For the cycling tests on symmetric cells of VSP-CoS ${ }_{2}||$ VSP-CoS 2 and $\mathrm{Li}|| \mathrm{Li}$ metal, the cells were charged/discharged at $1 \mathrm{~mA} \mathrm{~cm}-1$ for $1 \mathrm{mAh} \mathrm{cm}^{-1}$. VSP-CoS2 was used as the working electrode, and a lithium metal foil was used as the counter electrode. The test cells were discharged ( $\mathrm{Li}^{+}$insertion) and charged ( $\mathrm{Li}^{+}$extraction) galvanostatically at room temperature in the $0.01-3.0 \mathrm{~V}$ voltage window on a Neware CT-4008 battery tester. The electrochemically pre-lithiation process was discharged and charged for 5 cycles within $0.01-3.0 \mathrm{~V}$. To test the $\mathrm{LiMn}_{2} \mathrm{O}_{4}|| \mathrm{VSP}-\mathrm{CoS}_{2}$ full cell $(\sim 1$ $\mathrm{mAh}$ ), $\mathrm{LiMn}_{2} \mathrm{O}_{4}$ (LMO) electrodes were first fabricated by mixing the commercial $\mathrm{LiMn}_{2} \mathrm{O}_{4}$ powder (SEED Co., Ltd), acetylene 
black, and PVDF at a mass ratio of 8:1:1. A mixture of DMC/EC/, 7:3 by volume containing $1.0 \mathrm{M} \mathrm{LiPF}_{6}$ was used as the electrolyte of the LMO||VSP-CoS 2 full cell. The final areal mass loading of LMO and VSP-CoS 2 was approximately 8.3 and $0.29 \mathrm{mg} \mathrm{cm}^{-2}$, respectively. The cutoff potentials of charge and discharge were 4.4 and $3.3 \mathrm{~V}\left(v s \mathrm{Li}^{+} / \mathrm{Li}\right)$ for the $\mathrm{Li}-\mathrm{LiMn}_{2} \mathrm{O}_{4}$ model. After the VSP-CoS 2 anode was paired with the modified LMO cathode, the full cell had an activation process of five cycles.

\subsection{Characterization}

3D electron diffraction tomography (EDT) data and transmission electron microscopy (TEM) images were collected on a JEM-2100Plus at $200 \mathrm{kV}$. EDS mapping was performed on a JEM-1400Plus at $120 \mathrm{kV}$. The powder X-ray diffraction (PXRD) patterns of the materials were measured using a diffractometer (Bruker, Cu $K_{\alpha}$ with $\lambda=1.5406 \AA$, $40 \mathrm{kV} / 40 \mathrm{~mA}$ ). Scanning electron microscopy (SEM, Hitachi, SU8020) can be observed the morphology of catalyst. The TEM image, HRTEM image, STEM image, and EDS mapping were measured by TEM (JEOL, JEM-2100). The Brunauer-Emmett-Teller (BET) was measured using a Micromeritics ASAP 2020 instrument at $77 \mathrm{~K}$. The surface characteristics of VSP-CoS 2 were measured by Kratos AXIS $\mathrm{X}$-ray photoelectron spectroscopy (XPS).

\section{Results and discussion}

In a typical synthesis of VSP-MOFs, 1 mmol of $\mathrm{Co}\left(\mathrm{NO}_{3}\right)_{2}$ and $6 \mathrm{mmol}$ of Hmim were stirred into a mixture of water and methanol at a predetermined volume ratio $\left(V_{\text {water }} / V_{\text {methanol }}=\right.$ 3.5:1) at room temperature. SEM images showed that the hierarchical particle consisted of ultrathin nanosheets with a lateral length of hundreds of nanometers and a thickness of $\sim 20 \mathrm{~nm}$ (Fig. S1). Thin blade-shaped crystals form extraordinary $90^{\circ}$ rotational boundaries and a characteristic house-of-cards structure (Fig. 1(a)). The selected area electron diffraction (SAED) pattern taken along [111] of a VSP-MOF particle shows that all of the diffraction spots fit in a single reciprocal lattice of ZIF-67 (Fig. 1(b)) [49]. The illustrated house-of-card structure fits well with TEM images taken along [111] of the VSP-MOF particle (Fig. 1(c)). The 3D EDT technique was used to further investigate the structure. In total, 243 SAED frames were collected with a goniometer tilting from $-41.3^{\circ}$ to $37.7^{\circ}[50-54]$. Data were collected from the same particle along different orientations in a controlled way, and the reconstructed three-dimensional reciprocal lattice also proves the single-crystal nature of the samples (Figs. 1(d-f) and Video S1). These results indicate that the thin plates show a preferred orientation along the $<100>$ directions, and the intergrowth of plates with a perfect lattice match form the house-of-cards
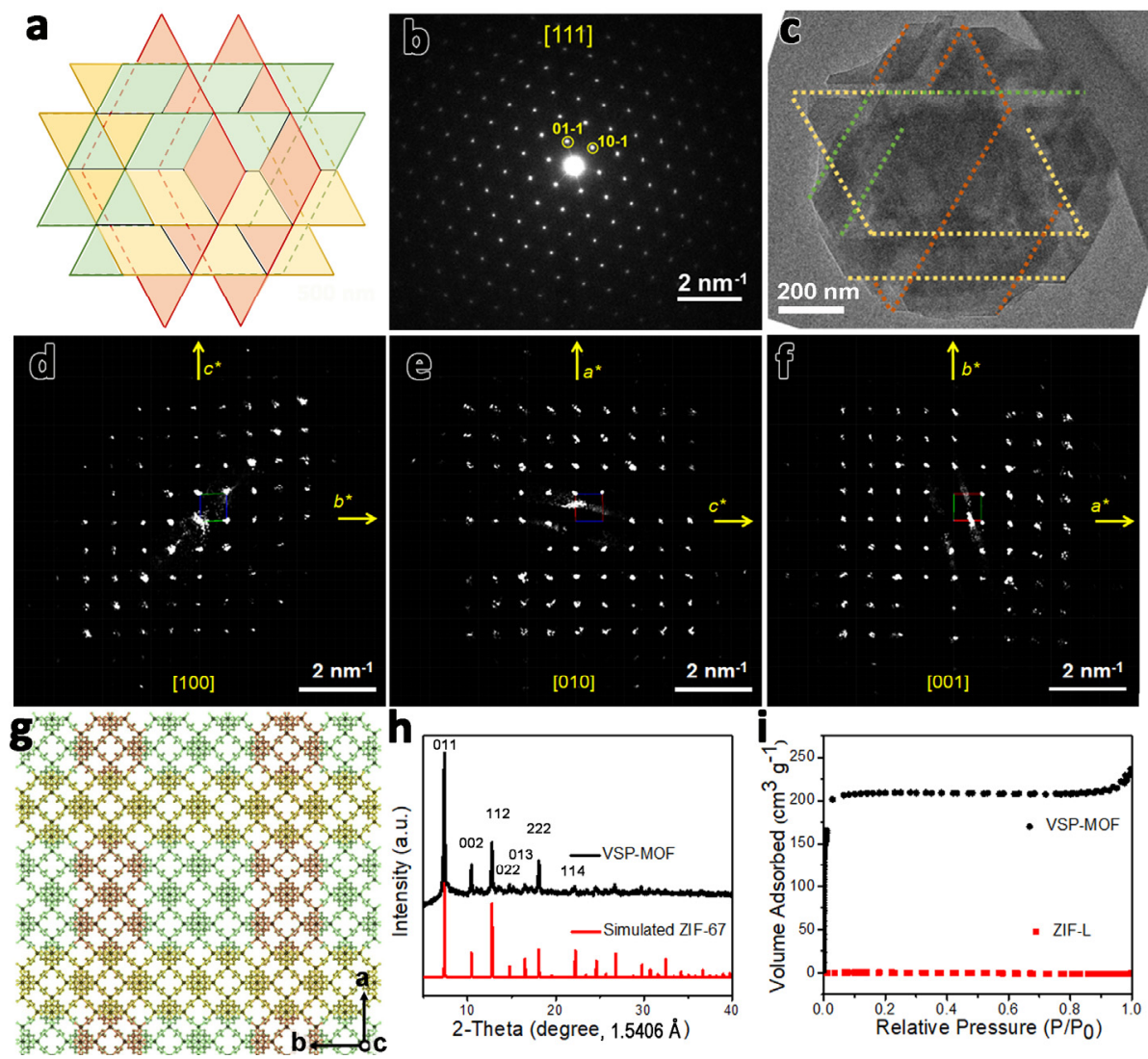

Fig. 1. Illustrating house-of-cards structure (a), selected area electron diffraction (SAED) pattern (b) and corresponding TEM image (c) along [111] of VSP-MOFs. Projection of reconstructed reciprocal lattice from 3D EDT data along [100] (d), [010] (e), [001] (f) directions, respectively. The crystal structural mode (g), experimental PXRD patterns (h) and $\mathrm{N}_{2}$ adsorption/desorption isotherm (i) of VSP-MOF and reference materials. 
structure with single crystallinity (Fig. 1 (g)). This means that an individual VSP-MOF is a single ZIF-67 crystal. The PXRD pattern of VSP-MOF shows intense and sharp diffraction peaks, indicating the formation of crystalline ZIF-67 (Fig. 1(h)). The BET surface area of VSP-MOF was $695 \mathrm{~m}^{2} \mathrm{~g}^{-1}$ (Fig. 1(i)). In summary, VSP-MOFs consisted of ultrathin nanosheets is a single crystal ZIF-67.

To investigate the formation mechanism of the VSP-MOF single crystal. In our synthesis, the products obtained after 20 min of reaction have a polyhedral morphology with the main phase of ZIF-67 (Fig. S2). After $1.5 \mathrm{~h}$ of reaction, several small nanosheets appeared on the outer surface, as observed in the SEM image. We then carried out PXRD to investigate its crystalline structure (Fig. S3). In the PXRD patterns, diffraction peaks assigned to a 2D stacked layer structure of ZIF-L(Co) appeared. ZIF-L(Co) has a 2D leaf-like morphology and is made up of the same building blocks as ZIF-67 (Fig. S4) [55]. In previous reports, scientists found that 3D ZIF-67 could be transferred to 2D ZIF-L(Co) when changing the solvent [56]. However, interestingly, after $2.5 \mathrm{~h}$ of reaction, VSP-MOF returned to a pure phase of ZIF-67. These results indicate that ZIF-L(Co) is found as an intermediate phase during synthesis and finally completely disappears in VSP-MOF. Based on the results described above, we propose a possible formation mechanism (Fig. S5). First, ZIF-67 nanoparticles are formed, and pure ZIF-67 is then transferred to a VSP structure in which 2D ZIF-L nanosheets with a lower-symmetry structure are connected by the higher-symmetry 3D ZIF-67 (Step 1). Finally, the ZIF-L changes back to ZIF-67 owing to the higher thermostability of ZIF-67 (Step 2). We performed control experiments to demonstrate that the two steps can happen. When changing the volume ratio of water to methanol, the crystalline structure and morphology can be easily tuned (Figs. S6 and S7). Therefore, the transformation between ZIF-67 and ZIF-L(Co) occurs during the reaction (Step 1). We also demonstrate that ZIF-L nanosheets can be transferred to ZIF-67 nanosheets while maintaining their morphology (Fig. S8, Step 2) [56]. Thus, the proposed formation mechanism is highly feasible.

After the transformation of VSP-MOFs, VSP-CoS 2 can be produced [57]. As shown in Figs. 2(a) and S9, the VSP morphology is well maintained after transformation and fits well with the proposed model. The high-resolution TEM image shows $d$-spacings of $0.2 \mathrm{~nm}$ and $0.32 \mathrm{~nm}$, assigned to the (220) and (111) planes of $\mathrm{CoS}_{2}$, respectively (Fig. 2(b)). Elemental mapping revealed a homogeneous distribution of Co and S (Fig. 2(c)). Diffraction peaks in the PXRD pattern of VSP-CoS 2 are indexed by $\mathrm{CoS}_{2}$ (JCPDS NO. 41-1471), which is consistent with the TEM results (Fig. 2(d)). The XPS survey of VSP-CoS 2 illustrates the existence of Co and S (Figs. 2(e,f), and S10). In XPS, the S/Co elements show a molar ratio of 2.11 , which is consistent with the theoretical value of 2 . Notably, the residual $\mathrm{C}$ and $\mathrm{N}$ in VSP-CoS 2 can also be observed in XPS. The peaks at $778.5 \mathrm{eV}$ in Co $2 p$ XPS and at $163.9 \mathrm{eV}$ in S $2 p$ XPS indicate the formation of metal-S in VSP-CoS 2 [58]. Therefore, the obtained VSP-CoS 2 not only retains the benefits from the VSP structure but is also functionalized with sulfur for Li-metal batteries.

To validate the properties of the VSP-CoS 2 composite as the anode, the VSP-CoS 2 assembled anode was directly explored $[59,60]$. The discharge and charge profiles of the assembled half cells during the $1^{\text {st }}, 15^{\text {th }}$, and $20^{\text {th }}$ cycles overlap, while the retrievable specific capacity was recorded as $\sim 324 \mathrm{mAh} \mathrm{g}^{-1}$ (Fig. 3(a)). The voltage profile of the VSP-CoS2 electrode illustrates the stepwise lithiation plateau at $\sim 1.7$ and $1.2 \mathrm{~V}$, while the charge plateau stabilizes at the plateau of $\sim 2$ and $2.3 \mathrm{~V}$,
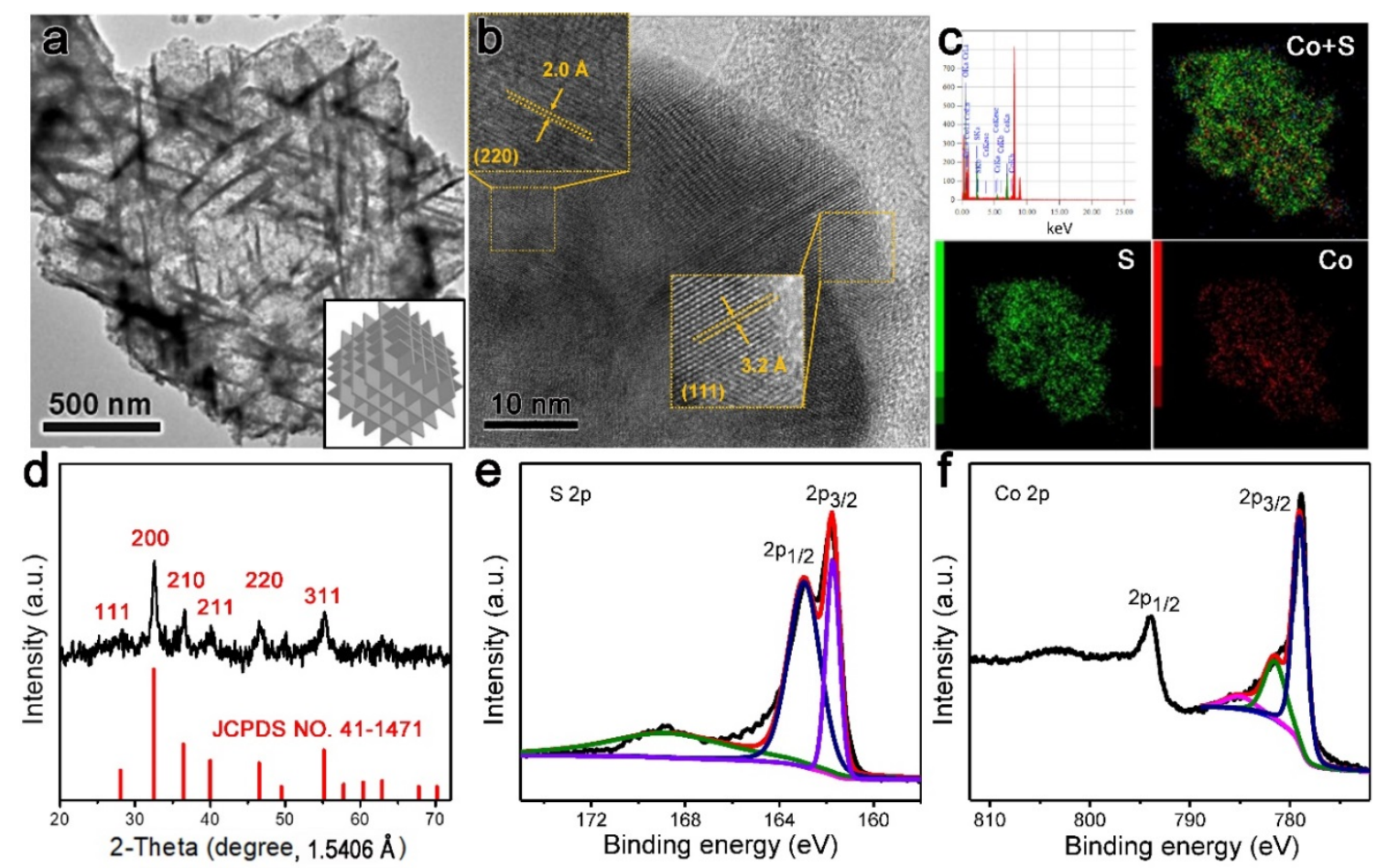

Fig. 2. TEM (a), HRTEM (b) images, EDS mapping (c), PXRD pattern (d), high-resolution XPS of Co $2 p$ (e) and S $2 p$ (f) of VSP-CoS2. 
corresponding to the reversible reaction of $\mathrm{CoS}_{2}+4 \mathrm{Li}=\mathrm{Co}+$ $2 \mathrm{Li}_{2} \mathrm{~S}$ above the $0 \mathrm{~V}$ ( vs $\left.\mathrm{Li}^{+} / \mathrm{Li}\right)$. Therefore, we purposely controlled the activation process until the voltage stage at $1.0 \mathrm{~V}$ (the charge process at the $3^{\text {rd }}$ cycle@0.5 $\mathrm{mA} \mathrm{cm}^{-2}$ ). When the voltage upper limitation was set to $1.0 \mathrm{~V}$ (the red dot marked in Fig. 3(a)), the VSP-CoS 2 composite anode comprised the zero-valent Co nanocrystals of $4 \mathrm{~nm}$ that were dispersed on the carbon nanosheets (Fig. S11). At the same time, the ion-conductive $\mathrm{Li}_{2} \mathrm{~S}$ matrix that covered the Co nanocrystals insulated the direct contact between the Li metallic embryos and the reactive electrolyte. The $d$-spacing is $0.208 \mathrm{~nm}$, indexed to the (111) planes of cubic metallic Co (PDF\# 15-806) (Fig. S11). Co nanoparticles were formed by the reaction of $\mathrm{CoS}_{2}$ with Li.

Fig. 3(b) compares the voltage profiles of the Li plating/stripping of VSP-CoS 2 and the bare Li foil at $1 \mathrm{~mA} \mathrm{~cm}^{-2}$ with a predetermined capacity of $1 \mathrm{mAh} \mathrm{cm}^{-2}$ [61]. The voltage profiles of VSP-CoS 2 in the symmetric Li cells exhibited a small hysteresis of $\sim 40 \mathrm{mV}$ during the continued cycling for $510 \mathrm{~h}$, whereas Li||Li symmetric cycling indicated easy failure after 110 h. As shown in Fig. 3(c), the amplified images of the voltage plateau almost mirrored the voltage hysteresis from 40 to 41 $\mathrm{mV}$ during the beginning $(0-5 \mathrm{~h})$ and end $(505-510 \mathrm{~h})$ of the $\mathrm{Li}$ plating/stripping process. In comparison, the Li||Li symmetric cycling showed a high overpotential of $\sim 73 \mathrm{mV}$ and an internal local short circuit after $112 \mathrm{~h}$.

Fig. 3(d) demonstrated stable capacity retention of the VSP-CoS 2 electrode after the activation process using the cutoff voltage of $1.0 \mathrm{~V}$ and the constant areal capacity of $1 \mathrm{mAh} \mathrm{cm}-2$ during $5^{\text {th }}, 15^{\text {th }}$, and $20^{\text {th }}$ cycles. The VSP-CoS 2 electrode showed a highly reversible Li deposition and stripping process and an overpotential hysteresis of $30 \mathrm{mV}$ (Fig. 3(d), inset). Compared with an abrupt voltage drop of bare $\mathrm{Cu}$ foil $(\sim 70 \mathrm{mV}), \mathrm{VSP}-\mathrm{CoS}_{2}$ electrode exhibited smaller Li nucleation overpotential of $\sim 30$ $\mathrm{mV}$ during the $1^{\text {st }}$ plating/stripping cycle (Fig. S12). The average CE value of the VSP-CoS 2 composite anode, from the $5^{\text {th }}$ cycle onwards, was more than 99.5\%@0.5 mA cm-2 (Fig. 3(e)). Additionally, the average CE value of the VSP-CoS 2 composite anode remained $97.5 \%$ and $95 \%$ at current density of 1 and 2 $\mathrm{mA} \mathrm{cm}-2$, respectively. In contrast, the $\mathrm{CE}$ of the bare $\mathrm{Cu}$ foil showed the $1^{\text {st }}$ cycle value of $85 \% @ 0.5 \mathrm{~mA} \mathrm{~cm}^{-2}$ and decreased to less than $60 \%$ after 100 cycles. When the current density increased to 1 and $2.0 \mathrm{~mA} \mathrm{~cm}^{-2}$, the bare $\mathrm{Cu}$ foil only showed the CE less than $50 \%$ due to the short circuit scenarios.

A full cell prototype (1 mAh, pouch cell) was constructed using the VSP-CoS 2 composite as the anode and $\mathrm{LiMn}_{2} \mathrm{O}_{4}$ as the cathode. The galvanostatic charge-discharge cycles of the $\mathrm{LiMn}_{2} \mathrm{O}_{4}$ cathode demonstrated a reversible capacity of $\sim 105$ $\mathrm{mAh} \mathrm{g}^{-1}$ at $1 \mathrm{C}$ upon continued cycling (Fig. S13). The LMO||VSP-CoS 2 full cell exhibited a discharge of $105 \mathrm{mAh}$ $\mathrm{g}^{-1}$ and charge capacities of $120 \mathrm{mAh} \mathrm{g}^{-1}$ at the $1^{\text {st }}$ cycle, resulting in a CE of $88 \%$. From the $2^{\text {nd }}$ cycle onwards, the

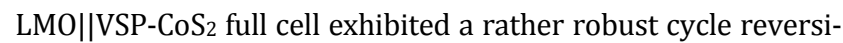
bility (Fig. 3(f)). The results show stable cycling for 200 cycles with an energy density of $457.6 \mathrm{Wh} \mathrm{kg}^{-1}$ (calculated using the electrode mass, Supporting information) [62]. The impressive performance was attributed to stabilized lithium deposition with a well-regulated propagation orientation. Therefore, we propose the dendrite suppression mechanism by the VSP structure as illustrated in Fig. 4. Compared with the amorphous carbon nanosheet, the catalytic Co particles tend to enhance the electrical field and favor electron transfer, creating nucleation sites for the metallic lithium embryos. At the same time, ion-conductive $\mathrm{Li}_{2} \mathrm{~S}$ covered on the metal surface insulates its direct contact with the reactive carbonate electrolyte, which accounts for the stabilized interfacial properties. The
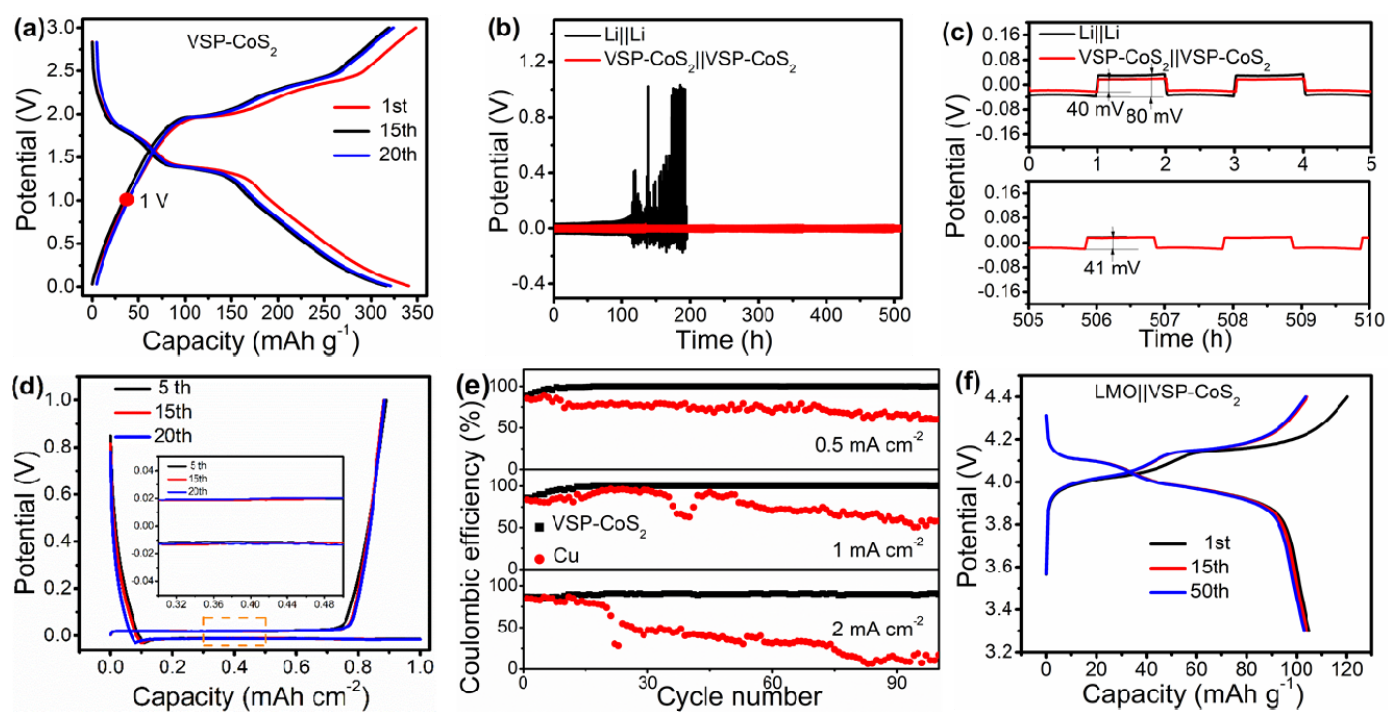

Fig. 3. Electrochemical characterization of the metallic batteries assembled by the VSP-CoS ${ }_{2}$ composite anodes. The discharge/charge profiles of (a) VSP-CoS $\mathrm{S}_{2}$ electrode at the selected cycles between 0 and 3 V; (b) Voltage-time profiles of the Li plating/stripping of VSP-CoS 2 ||VSP-CoS 2 and Li||Li@1 $\mathrm{mA} \mathrm{cm}-2$ with the predetermined capacity of $1 \mathrm{mAh} \mathrm{cm}-2$ for $510 \mathrm{~h}$ in symmetric cells; (c) The enlarged view of the voltage-time curve of the VSP-CoS 2 |VSP-CoS 2 and Li||Li cells during 0 to $5 \mathrm{~h}$ symmetric cycling; (d) Voltage profiles of the VSP-CoS $\mathrm{V}_{2}$ electrode after activation process for different cycles with the upper cutoff voltage of $1.0 \mathrm{~V}$ at $5 \mathrm{~mA} \mathrm{~cm}^{-2}$; The inset in Fig. 3(d) presents the enlarged voltage profile. (e) CE of the VSP-CoS 2 composite and the bare $\mathrm{Cu}$ foil for 100 cycles@0.5, 1, and $2 \mathrm{~mA} \mathrm{~cm}^{-2}$; (f) Galvanostatic discharge-charge curves of LMO||VSP-CoS2 full cell during different cycles. 


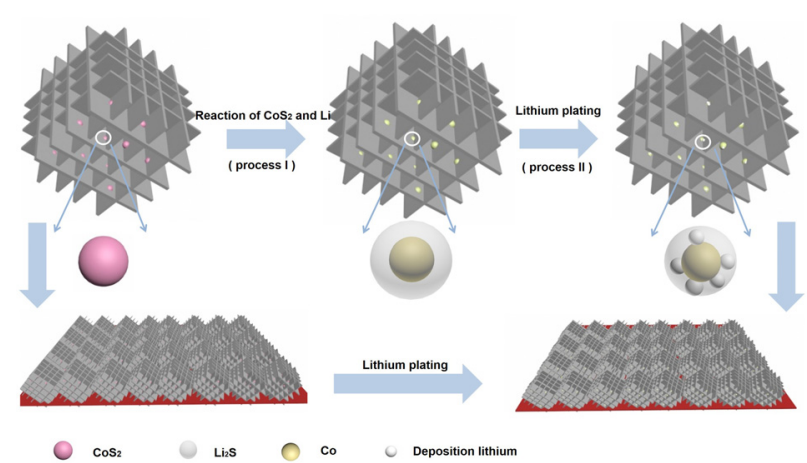

Fig. 4. Schematic illustration of the Li plating in the VSP-CoS $\mathrm{S}_{2}$ composite at different cycling states.

well-percolated VSP structure guarantees the homogenized ion flux for the propagation of the lithium nucleates along the nanosheet orientation.

We further investigated the reason that the battery assembled by VSP- $\mathrm{CoS}_{2}$ showed impressive performance and high stability. As the voltage was discharged below $0 \mathrm{~V}$ for lithium plating, the TEM image of the VSP structures exhibited uniform deposition of Li metal on the nanosheet, as indicated by the arrows (Fig. S14). The activation process is shown in Fig. 3(a). As the voltage was recharged to over $1 \mathrm{~V}$, the TEM image of the VSP-CoS 2 composite exhibited complete lithium stripping from the nanosheet surface (Fig. S15(a)) and exhibited high levels of dispersion of catalytic Co on the amorphous matrix phase (Fig. S15(b)). The SAED pattern demonstrates the (111) plane of metallic Co and the (002) plane of graphitic C, suggesting the co-existence of Co and C (Fig. S15(c)). The EDS elemental maps of the VSP-CoS 2 composite showed a uniform distribution of Co, $\mathrm{S}$, and $\mathrm{C}$ on the layered structure after the lithium stripping process (Figs. S15(d)-(g)). The post-mortem morphological characterizations of the VSP-CoS 2 electrode validate the well-maintained flat surface of the VSP structure without dendrite formation at the plated state of the $100^{\text {th }}$ cycle (Fig. S16).

\section{Conclusions}

We successfully prepared a VSP-MOF, which is a single crystal of ZIF-67 from an individual particle. A possible formation mechanism is proposed based on PXRD and TEM results, as well as careful control experiments. After transformation, VSP-CoS 2 is obtained by maintaining the VSP architecture from the parental VSP-MOF, provides a high specific surface area to dissipate the ion flux and mass transfer and acts as a pre-catalyst for metallic batteries. When loading these 3D frameworks to obtain the deposited lithium in the metallic batteries, the battery assembled by VSP-CoS 2 provides an effective current density, high average CE (99\%), reduced nucleation hysteresis ( $30 \mathrm{mV}$ at $5 \mathrm{~mA} \mathrm{~cm}-2)$, and stabilized cycling $(510 \mathrm{~h})$. This study is important for the rational design of the VSP structure and its applications in metallic batteries.

\section{Acknowledgement}

We thank CћEM SPST [02161943] for TEM measurements.

\section{Electronic supporting information}

Supporting information is available in the online version of this article.

\section{Author Contributions}

$\mathrm{X}$. Jia designed and synthesized the VSP-MOF and its derived materials, performed SEM, PXRD and $\mathrm{N}_{2}$ adsorption-desorption isotherm with the assistance of Y. Wang. S. Li constructed the Li-metal battery and tested the activity under the supervision of Prof. Yue Ma. TEM, HRTEM and SAED patterns were taken by T. Sun, Y. Fan and Yanhang Ma. C. Zhang carried out HRTEM measurements and EDS mapping. Y. Xu and Y. Zhou performed XPS measurements, contributed to XPS analysis, prepared and revised the manuscript. Z. Liang and H. Lei collected PXRD, and built the structure model for VSP-MOFs and VSP-CoS 2 s. Prof. W. Zhang contributed to XPS analysis and revised the manuscript. X. Jia, H. Zheng, Yue Ma and Prof. R. Cao prepared this manuscript. H. Zheng, Yue Ma and R. Cao guided all aspects of this work. The manuscript was written through contributions of all authors. All authors have given approval to the final version of the manuscript.

\section{Conflict of interest}

The authors declare that they have no conflict of interest.

\section{References}

[1] H. Deng, C. J. Doonan, H. Furukawa, R. B. Ferreira, J. Towne, C. B. Knobler, B. Wang, O. M. Yaghi, Science, 2010, 327, 846-850.

[2] S. Mitchell, A. B. Pinar, J. Kenvin, P. Crivelli, J. Kärger, J. Pérez-Ramírez, Nat. Commun., 2015, 6, 8633.

[3] V. Valtchev, L. Tosheva, Chem. Rev., 2013, 113, 6734-6760.

[4] W. Li, J. Liu, D. Zhao, Nat. Rev. Mater., 2016, 1, 16023.

[5] M. Zhao, Y. Huang, Y. Peng, Z. Huang, Q. Ma, H. Zhang, Chem. Soc. Rev., 2018, 47, 6267-6295.

[6] W. Zhou, D.-D. Huang, Y.-P. Wu, J. Zhao, T. Wu, J. Zhang, D.-S. Li, C. Sun, P. Feng, X. Bu, Angew. Chem. Int. Ed., 2019, 58, 4227-4231.

[7] J. Ran, J. Qu, H. Zhang, T. Wen, H. Wang, S. Chen, L. Song, X. Zhang, L. Jing, R. Zheng, S.-Z. Qiao, Adv. Energy Mater., 2019, 9, 1803402.

[8] J. Zhou, B. Wang, Chem. Soc. Rev., 2017, 46, 6927-6945.

[9] H. Zhong, K. H. Ly, M. Wang, Y. Krupskaya, X. Han, J. Zhang, J. Zhang, V. Kataev, B. Büchner, I. M. Weidinger, S. Kaskel, P. Liu, M. Chen, R. Dong, X. Feng, Angew. Chem. Int. Ed., 2019, 58, 10677-10682.

[10] W. Xia, J. Tang, J. Li, S. Zhang, K. C. W. Wu, J. He, Y. Yamauchi, Angew. Chem. Int. Ed., 2019, 58, 13354-13359.

[11] M. Pan, Y.-X. Zhu, K. Wu, L. Chen, Y.-J. Hou, S.-Y. Yin, H.-P. Wang, Y.-N. Fan, C.-Y. Su, Angew. Chem. Int. Ed., 2017, 56, 14582-14586.

[12] Y. Luo, M. Ahmad, A. Schug, M. Tsotsalas, Adv. Mater., 2019, 31, 1901744.

[13] L. Feng, K.-Y. Wang, J. Powell, H.-C. Zhou, Matter, 2019, 1, 801-824.

[14] H. Zheng, Y. Zhang, L. Liu, W. Wan, P. Guo, A. M. Nyström, X. Zou, J. Am. Chem. Soc., 2016, 138, 962-968. 
[15] J. Tang, R. R. Salunkhe, J. Liu, N. L. Torad, M. Imura, S. Furukawa, Y. Yamauchi, J. Am. Chem. Soc., 2015, 137, 1572-1580.

[16] Z. Hassan, Y. Matt, S. Begum, M. Tsotsalas, S. Bräse, Adv. Funct. Mater., 2020, 1907625.

[17] Y. C. Tan, H. C. Zeng, Adv. Funct. Mater., 2017, 27, 1703765.

[18] Y. Kim, T. Yang, G. Yun, M. B. Ghasemian, J. Koo, E. Lee, S. J. Cho, K. Kim, Angew. Chem. Int. Ed., 2015, 54, 13273-13278.

[19] X. Zhang, D. Liu, D. Xu, S. Asahina, K. A. Cychosz, K. V. Agrawal, Y. Al Wahedi, A. Bhan, S. Al Hashimi, O. Terasaki, M. Thommes, M. Tsapatsis, Science, 2012, 336, 1684.

[20] D. Xu, Y. Ma, Z. Jing, L. Han, B. Singh, J. Feng, X. Shen, F. Cao, P. Oleynikov, H. Sun, O. Terasaki, S. Che, Nat. Commun., 2014, 5, 4262.

[21] C. Huang, J. Dong, W. Sun, Z. Xue, J. Ma, L. Zheng, C. Liu, X. Li, K. Zhou, X. Qiao, Q. Song, W. Ma, L. Zhang, Z. Lin, T. Wang, Nat. Commun., 2019, 10, 2779.

[22] B.-Q. Li, S.-Y. Zhang, L. Kong, H.-J. Peng, Q. Zhang, Adv. Mater., 2018, 30, 1707483.

[23] Q. Jiang, P. Xiong, J. Liu, Z. Xie, Q. Wang, X.-Q. Yang, E. Hu, Y. Cao, J. Sun, Y. Xu, L. Chen, Angew. Chem. Int. Ed., 2020, 59, 5273-5277.

[24] Q. Jiang, Y. Li, X. Zhao, P. Xiong, X. Yu, Y. Xu, L. Chen, J. Mater. Chem. A, 2018, 6, 17977-17981.

[25] G. Xu, P. Nie, H. Dou, B. Ding, L. Li, X. Zhang, Mater. Today, 2017, 20, 191-209.

[26] Y. Zheng, S. Zheng, H. Xue, H. Pang, J. Mater. Chem. A, 2019, 7, 3469-3491.

[27] R. Zhao, Z. Liang, R. Zou, Q. Xu, Joule, 2018, 2, 2235-2259.

[28] S. Bai, X. Liu, K. Zhu, S. Wu, H. Zhou, Nat. Energy, 2016, 1, 16094.

[29] D. Wu, Z. Guo, X. Yin, Q. Pang, B. Tu, L. Zhang, Y.-G. Wang, Q. Li, Adv. Mater., 2014, 26, 3258-3262.

[30] G. Huang, F. Zhang, X. Du, Y. Qin, D. Yin, L. Wang, ACS Nano, 2015, 9, 1592-1599.

[31] L. Jiao, J. Y. R. Seow, W. S. Skinner, Z. U. Wang, H.-L. Jiang, Mater. Today, 2019, 27, 43-68.

[32] Z. C. Wu Qianye, Sun Kang, Jiang Hai-Long, Acta Chim. Sin., 2020, 78, 688-694.

[33] Z. Xue, K. Liu, Q. Liu, Y. Li, M. Li, C.-Y. Su, N. Ogiwara, H. Kobayashi, H. Kitagawa, M. Liu, G. Li, Nat. Commun., 2019, 10, 5048.
[34] K. Chen, K. Liu, P. An, H. Li, Y. Lin, J. Hu, C. Jia, J. Fu, H. Li, H. Liu, Z. Lin, W. Li, J. Li, Y.-R. Lu, T.-S. Chan, N. Zhang, M. Liu, Nat. Commun., 2020, 11, 4173.

[35] D. Lin, Y. Liu, Y. Cui, Nat. Nanotechnol., 2017, 12, 194-206.

[36] D. A. Dornbusch, R. Hilton, S. D. Lohman, G. J. Suppes, J. Electrochem. Soc., 2014, 162, A262-A268.

[37] W. Liu, W. Li, D. Zhuo, G. Zheng, Z. Lu, K. Liu, Y. Cui, ACS Cent. Sci., 2017, 3, 135-140.

[38] M. Ye, Y. Xiao, Z. Cheng, L. Cui, L. Jiang, L. Qu, Nano Energy, 2018 49, 403-410.

[39] J. Wen, Y. Huang, J. Duan, Y. Wu, W. Luo, L. Zhou, C. Hu, L. Huang, X. Zheng, W. Yang, Z. Wen, Y. Huang, ACS Nano, 2019, 13, 14549-14556.

[40] R. Pan, R. Sun, Z. Wang, J. Lindh, K. Edström, M. Strømme, L. Nyholm, Nano Energy, 2019, 55, 316-326.

[41] Y. Huang, B. Chen, J. Duan, F. Yang, T. Wang, Z. Wang, W. Yang, C. Hu, W. Luo, Y. Huang, Angew. Chem. Int. Ed., 2020, 59, 3699-3704.

[42] Q. Chen, Y. Yang, H. Zheng, Q. Xie, X. Yan, Y. Ma, L. Wang, D.-L. Peng, J. Mater. Chem. A, 2019, 7, 11683-11689.

[43] P. Xue, S. Liu, X. Shi, C. Sun, C. Lai, Y. Zhou, D. Sui, Y. Chen, J. Liang, Adv. Mater., 2018, 30, 1804165.

[44] R. Song, B. Wang, Y. Xie, T. Ruan, F. Wang, Y. Yuan, D. Wang, S. Dou, J. Mater. Chem. A, 2018, 6, 17967-17976.

[45] B. Zhu, Y. Jin, X. Hu, Q. Zheng, S. Zhang, Q. Wang, J. Zhu, Adv. Mater., 2017, 29, 1603755.

[46] R. Zhang, N.-W. Li, X.-B. Cheng, Y.-X. Yin, Q. Zhang, Y.-G. Guo, Adv. Sci., 2017, 4, 1600445.

[47] R. Zhang, X. Chen, X. Shen, X.-Q. Zhang, X.-R. Chen, X.-B. Cheng, C. Yan, C.-Z. Zhao, Q. Zhang, Joule, 2018, 2, 764-777.

[48] Y. Ma, S. Li, B. Wei, Nanoscale, 2019, 11, 20429-20436.

[49] R. Banerjee, A. Phan, B. Wang, C. Knobler, H. Furukawa, M. Keeffe, O. M. Yaghi, Science, 2008, 319, 939.

[50] P. Guo, J. Shin, A. G. Greenaway, J. G. Min, J. Su, H. J. Choi, L. Liu, P. A. Cox, S. B. Hong, P. A. Wright, X. Zou, Nature, 2015, 524, 74-78.

[51] Y. Liu, Y. Ma, Y. Zhao, X. Sun, F. Gándara, H. Furukawa, Z. Liu, H. Zhu, C. Zhu, K. Suenaga, P. Oleynikov, A. S. Alshammari, X. Zhang, O. Terasaki, O. M. Yaghi, Science, 2016, 351, 365.

[52] D. Zhang, P. Oleynikov, S. Hovmoeller, X. Zou, Z. Kristallogr., 2010,

\section{Graphical Abstract}

Chin. J. Catal., 2021, 42: 1553-1560 doi: 10.1016/S1872-2067(20)63755-X

Single crystal metal-organic framework constructed by vertically self-pillared nanosheets and its derivative for oriented lithium plating

Xiaomin Jia', Shaowen $\mathrm{Li}^{\dagger}, \mathrm{Tu}$ Sun', Yanzhi Wang', Yaqi Fan, Chaochao Zhang, Yang Xu, Zuozhong Liang, Haitao Lei, Wei Zhang, Yuye Zhou, Yanhang Ma, Haoquan Zheng *, Yue Ma *, Rui Cao*

Shaanxi Normal University, China;

Northwestern Polytechnical University, China;

ShanghaiTech University, China;

KTH Royal Institute of Technology, Sweden

A single crystal metal-organic framework constructed by vertically self-pillared nanosheets has been prepared. Derived VSP-cobalt sul-

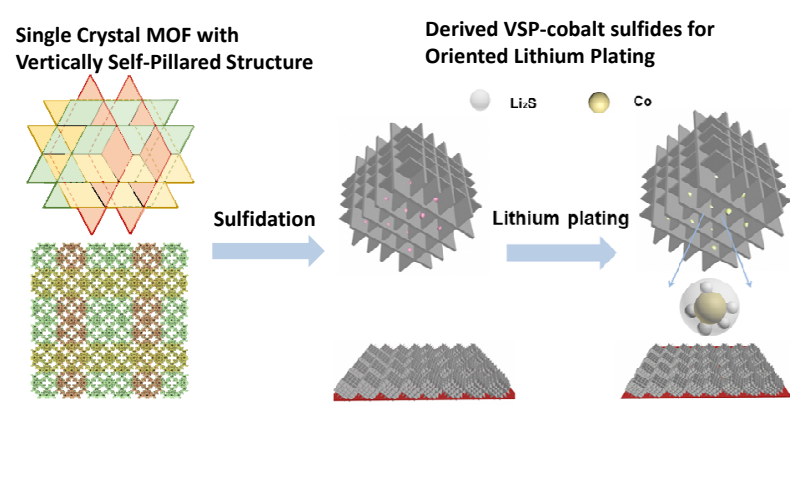
fides were employed for oriented lithium plating in metallic batteries. 
$225,94-102$.

[53] M. Gemmi, P. Oleynikov, Z. Kristallogr., 2013, 228, 51-58.

[54] B. Wang, X. Zou, S. Smeets, IUCrJ, 2019, 6, 854-867.

[55] R. Chen, J. Yao, Q. Gu, S. Smeets, C. Baerlocher, H. Gu, D. Zhu, W. Morris, O. M. Yaghi, H. Wang, Chem. Commun., 2013, 49, 9500-9502.

[56] J. Guan, Y. Hu, Y. Wang, H. Li, Z. Xu, T. Zhang, P. Wu, S. Zhang, G. Xiao, W. Ji, L. Li, M. Zhang, Y. Fan, L. Li, B. Zheng, W. Zhang, W. Huang, F. Huo, Adv. Mater., 2017, 29, 1606290.

[57] Z.-F. Huang, J. Song, K. Li, M. Tahir, Y.-T. Wang, L. Pan, L. Wang, X. Zhang, J.-J. Zou, J. Am. Chem. Soc., 2016, 138, 1359-1365.
[58] X. Han, X. Wu, Y. Deng, J. Liu, J. Lu, C. Zhong, W. Hu, Adv. Energy Mater., 2018, 8, 1800935.

[59] R. Jin, J. Zhou, Y. Guan, H. Liu, G. Chen, J. Mater. Chem. A, 2014, 2 , 13241-13244.

[60] B. Yin, X. Cao, A. Pan, Z. Luo, S. Dinesh, J. Lin, Y. Tang, S. Liang, G. Cao, Adv. Sci., 2018, 5, 1800829.

[61] F. Liu, Q. Xiao, H. B. Wu, L. Shen, D. Xu, M. Cai, Y. Lu, Adv. Energy Mater., 2018, 8, 1701744.

[62] E. Cha, M. D. Patel, J. Park, J. Hwang, V. Prasad, K. Cho, W. Choi, Nat. Nanotechnol., 2018, 13, 337-344.

\section{垂直自支撑式金属有机框架多级结构单晶用于锂定向沉积}

贾晓敏 ${ }^{\mathrm{a}, \dagger}$, 李少雯 ${ }^{\mathrm{b}, \dagger}$, 孙 凸 $^{\mathrm{c}, \dagger}$, 王彦智 ${ }^{\mathrm{a}, \dagger}$, 范亚奇 ${ }^{\mathrm{c}}$, 张超超 ${ }^{\mathrm{a}}$, 徐 杨 $^{\mathrm{a}}$, 梁作中 ${ }^{\mathrm{a}}$, 雷海涛 ${ }^{\mathrm{a}}$,

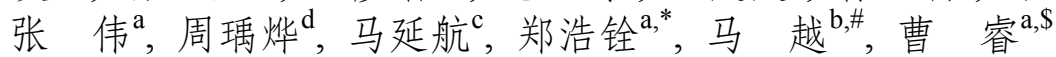

${ }^{a}$ 陕西师范大学化学化工学院, 应用表面与胶体化学教育部重点实验室, 陕西西安710119, 中国 $\mathrm{b}^{\mathrm{b}}$ 西北工业大学材料学院, 凝固技术国家重点实验室, 纳米能源材料研究中心, 陕西西安 710072 , 中国 ' 上海科技大学物质科学与技术学院, 上海201210, 中国

瑞典皇家理工学院化学生物技术和健康学院, 化学院, 应用物理化学系, 分析化学, 斯德哥尔摩, 瑞典

摘要: 金属有机框架材料(MOF)是由金属离子或簇和有机配体通过配位键自组装形成的多孔晶体材料. MOF及其衍生物 具有开放金属位点和极大的比表面积, 广泛地应用在催化领域. 然而, MOF材料由于存在暴露活性位点较少, 传质受限或 易发生不可控制的聚集等问题, 会导致活性位点的损失, 极大地限制了其在催化领域的应用. 多级结构不仅提供更多的暴 露活性位点, 而且提升传质效率及稳定性. 因此, 设计和构造分层多级结构的MOF材料是解决上述问题的有效途径. 本文 制备了一种垂直自支撑式MOF多级结构材料. 该多级结构材料由相互垂直自支撑式纳米片所构成; 通过三维电子衍射表 征显示, 单个垂直自支撑式MOF多级结构颗粒显示单晶特性. 因此, 可以确定垂直自支撑式MOF多级结构是ZIF-67的单晶. 本文也对这种结构的形成机理进行了初步探究, 两种具有结构相关性ZIF在混合溶液中的相互转化是主要驱动力. 这种垂 直穿插的多级结构具有优异的传质/传荷能力和增强反应动力学的特性, 扩展了传统多孔晶体材料的应用领域.

本文通过温和的溶液硫化法, 制备了保留垂直穿插结构的硫化钴, 并进一步将这种垂直穿插结构的硫化钴应用在锂金 属电池中. 这类材料显示出多个优点: (1)具有高比表面积, 提升了离子通量和传质; (2)锂离子的结合将硫化钴物种还原为 钴金属颗粒; (3)垂直穿插结构引导金属沿着二维纳米片的方向沉积, 避免树枝状晶体的生成. 将这种垂直自支撑式硫化钴 多级结构材料用作电极材料时, 所组装的锂金属电池显示出有效的电流密度、高库伦效率 $(99 \%)$ 、低成核过电位 $(30 \mathrm{mV}$ 于 $5 \mathrm{~mA} \mathrm{~cm}{ }^{-2}$ ) 和较好的稳定循环性 $(510 \mathrm{~h})$. 本文对于垂直穿插结构材料的设计及研究其在金属电池中的应用具有重大意义. 关键词：垂直自支撑式结构; 金属有机框架材料; 催化剂前驱体; 锂定向沉积; 金属电池

收稿日期: 2020-12-11. 接受日期: 2021-01-11. 上网时间: 2021-05-05.

*通讯联系人. 电子信箱: zhenghaoquan@snnu.edu.cn

\#通讯联系人. 电子信箱: mayue04@nwpu.edu.cn

\$通讯联系人. 电子信箱: ruicao@snnu.edu.cn

†共同第一作者.

基金来源：国家自然科学基金(21975148, 51602261, 51711530037, 21773146, 21835002, 21875140, 21601118); 教育部霍英东青年 教师基金; 中央高校基础研究基金(GK201903033, 3102019JC005); 上海市自然科学基金(17ZR1418600).

本文的电子版全文由Elsevier出版社在ScienceDirect上出版(http://www.sciencedirect.com/journal/chinese-journal-of-catalysis). 